\title{
The potential of regulating ecosystem service - filtering potential for inorganic pollutants - supplied by soils of Slovakia
}

\author{
JARMILA MAKOVNÍKOVÁ ${ }^{1}$, Boris PÁLKA ${ }^{1}$, MILOŠ ŠIRÁŇ ${ }^{2}$, \\ Miroslava KIZEKOV Á ${ }^{2}$ and Radoslava KANIANSKA ${ }^{3}$
}

\begin{abstract}
The concept of agroecosystem services combines environmental and socio-economic approaches to the analysis and evaluation of natural capital. A multi-criteria approach to spatial quantification of ecosystem services allows explicit assessment of the potential of agroecosystems to provide agroecosystem services and to adapt the land management under regional conditions. For the spatial quantifying of agroecosystem services potential of agricultural land in Slovakia, we have created a mapping unit by combining four input layers (climatic region, slope topography, soil texture and land use). In ecosystems of agricultural land, regulation of water regime, control of soil erosion, climate regulation and soil filtration are the main regulating services. Filtering potential was calculated as accumulative function of soil sorption potential and potential of total content of inorganic pollutants evaluated according to The Slovak Soil Law. Calculated potential was categorised into five categories (very low, low, medium, high and very high). The distribution of the filtering potential using spatial mapping units show that in Slovakia more than 41 per cent of agroecosystems have very high filtering potential (for inorganic pollutants), mostly in the Bratislava, Nitra and Trnava regions. Ecosystems with low potential (more than 41 per cent of agricultural land) are predominantly located on Fluvisols (along Váh, Hron and Bodrog rivers) with a higher content of risk elements in alluvial sediments (caused by anthropogenic deposition). The mountain soils on grassland are also strongly involved in very low category of filtering potential, predominantly in the Banská Bystrica, Žilina and Prešov regions. The greatest differences among regions was found in relation to climatic conditions, land use and the diversity of soil types.
\end{abstract}

Keywords: ecosystem services, soil pollutants, filtering potential, Slovakia, district, region

\section{Introduction}

Ecosystem services are the benefits that natural capital provides to society. Ecosystem services represent an interaction between ecological and social systems as only those ecosystem processes that contribute to the fulfilment of human needs are defined as ecosystem services (Birghofer, K. et al. 2015). According to Costanza, R. et al. (2017) the connections between ecosystem processes, functions and benefits to humankind are non-linear and dynamic. Dominati, E.J. et al. (2010) divided ecosystem services linked to natural capital into three main categories (provisioning, regulating and cultural). The concept of ecosystem services represents a bridge between ecological and economical approaches and helps to create a transdisciplinary ecological economy (Haines-Young, R. et al. 2012). This concept brings a new comprehensive view on the issue of effective use of natural goods not only from

\footnotetext{
${ }^{1}$ National Agricultural and Food Centre/ Soil Science and Conservation Research Institute Bratislava, Regional Station Banská Bystrica, Mládežnícka 36, 97404 Banská Bystrica, Slovakia. Correspondent author’s e-mail: j.makovnikova@nppc.sk

${ }^{2}$ National Agricultural and Food Centre / Grassland and Mountain Agriculture Research Institute, Mládežnícka 36, 97404 Banská Bystrica, Slovakia.

${ }^{3}$ Department of Environment, Faculty of Natural Sciences, Matej Bel University Národná 12, 97401 Banská Bystrica, Slovakia.
} 
the point of view of production but additionally from the point of view of all services provided by ecosystems. The concept of ecosystem services can be included in land use planning and decision support tools (BURGHARD, B. and MAEs, J. 2017; SPAKE, R. et al. 2017).

Agricultural systems are intensely managed, controlled and regulated by humans (Dominati, E.J. et al. 2010). We consider the agroecosystem not only as a means of production but also as a part of the natural environment, where the pedosphere is multifunctional in terms of its processes, functions and services (MEA 2005; Burghard, B. et al. 2014; Coyle, C. et al. 2016). Agroecosystems, such as arable land and grassland, are mostly biotopes for only a few plant and animal species and are very poor in terms of biodiversity because of the targeted cultivation of monocultures. On the other hand, agricultural land significantly contributes to the fulfilment of regulating services (potential of water regime regulation filtration potential). RoDRíGUEZ, J.P.et al. (2006) noticed that when regulating services are providing they are more likely to be taken for granted and therefore less attention is paid to their evaluation in agroecosystems. According to Burghard, B. et al. (2014) we consider ecosystem services potential (capacity) as the hypothetical maximum yield of ecosystem services.

Regulating services are benefits created by the self-sustaining capabilities of ecosystems, the regulation of ecosystem processes. All these services are not directly consumed by man as goods, but regulating services do bring many direct benefits by keeping safe and habitable environments, supporting food production systems or processing and removing waste and pollution (BURGHARD, B. and MAEs, J. 2017). In ecosystems of the agricultural land, regulation of water regime, control of soil erosion, climate regulation and soil filtration of pollutants are the main regulating services (Dominati, E.J. 2013). The filtering capacity of soil refers to its ability to retain nutrients and contaminants bonding them with varying intensity (from weak to strong) to organic or mineral soil constituents, and thereby preventing their release into water passing through the soil profile (Burghard, B. and MAEs, J. 2017). Inappropriate land management can lead to land degradation and thus can reduce the provision of agroecosystem services (DendonCKer, N. et al. 2018). However, in the present widespread scenario of multiple problems including land degradation and land pollution, there is a need to address regulating services, including soil filtration, in an objective manner.

Techniques that are often used to evaluate and map ecosystem services are expert-based estimations, expert-scoring, through land use classes and land use cover (BURKHARD, B. et al. 2009) or participatory GIS mapping (MAES, J. et al. 2018). The concept of natural capital and agroecosystem services are widely accepted and their potential contribution to better environmental management is also acknowledged (MEA 2005). However, their practical applications such as distribution and mapping are still insufficient and limited. Biophysical indicators (soil quality indicators) as well as localization and changes over space and time due to human induced land cover and land use are used by many authors to evaluate ecosystem services (Dominati, E.J. et al. 2010; Alam, M. et al. 2016). The quantification and mapping of ecosystem services distribution is also considered one of the main requirements for the implementation of the concept of ecosystem services into institutional decision-making.

The aim of this study was to evaluate and map regulating agroecosystem service (filtration potential for inorganic pollutants) in regions and districts of Slovak Republic.

\section{Material and method}

Filtering potential for soil pollutants depends on actual soil contamination and the potential of soil sorbents that are sensitive to the sorption of risk elements. Higher amounts of potential risk elements in the soils takes up the potential sorbent places and consequently reduces the overall soil potential for the sorption of the risk elements. 
Filtering potential was calculated as accumulative function:

$$
F P=S P+K
$$

where $F P=$ filtering potential; $S P=$ sorption potential of soil, $K=$ potential of total content of inorganic contaminants evaluated according to The Slovak Law 220/2004 Z.

The evaluation of sorption potential of soil $(S P)$ was calculated as a sum of quality factors $\left(\mathrm{pH}, \mathrm{Q}_{4}{ }^{6}\right)$ and quantity factors (Cox, $\mathrm{H}$-depth of humus horizon) according to function:

$$
S P=F(\mathrm{pH})+F\left(\mathrm{Q}_{4}{ }^{6}\right)+F(\mathrm{Cox}) \cdot F(\mathrm{H})
$$

Values were categorised into five categories as follows: 1 - very low relevant capacity (more than 6.50 points), category 2 - low relevant capacity (5.51-6.50 points), category 3 medium relevant capacity (4.51-5.50 points), category 4 - high relevant capacity (3.50-4.50 points), category 5 - very high relevant capacity (lower than 3.50 points). The method is described in detail in our previous article Makovníková, J. et al. (2007).

\section{Mapping units}

ForouzAngohar, M. et al. (2014) concluded that one of the best sampling and mapping strategies would be a regular grid scheme. For spatial quantification of regulating agroecosystem services of agricultural land in Slovakia, we have created a mapping unit by combining four input layers:

1. Climatic region (categories: moderately cold, moderately warm, warm and very warm);

2. Slope topography (categories: $0.0^{\circ}-2.0^{\circ}$, $2.1^{\circ}-5.0^{\circ}, 5.1^{\circ}-12.0^{\circ}$, and over $12.0^{\circ}$ );

3. Soil texture (categories: soil particles $<0,01$ mm less than $20 \%, 20-45 \%$, and over $45 \%$ );

4. Land use (arable land, grassland and other cultures like sets, vineyards, hops).

Each mapping unit represents one cell of $100 \mathrm{~m}$ resolution in regular grid derived from
EEA reference grid. Mapping units are compatible with the spatial units in international database (Corine Land Cover). We calculated a weighted average of the filtration potential for each mapping unit. Software package of the geographic information system ArcGIS® was used for processing the input geo-referenced digital data and the resulting maps.

For each region and district we calculated a weighted average of individual categories (of all grids that belong to a particular region or district) of filtering potential. The weighted average, in contrast to the average, takes into account the spatial distribution (area representation) of each category. Software package of the geographic information system ArcGIS ${ }^{\circledR}$ was used for processing the input geo-referenced digital data and the resulting maps. Moreover, the methodology developed in this paper is replicable and can be applied by planners if they are proficient in geographic information systems.

\section{Data sources}

Available data sources for the categorization and mapping consisted of primary (spatial information on the soil bodies) and secondary (data of relevant soil properties) geo-referenced data. Data from the Geochemical Atlas of Soils of Slovakia, data from the Digital Soil Map of Slovakia and data of Soil Monitoring of Slovakia were used to evaluate the potential of total content of inorganic contaminants in soil and sorption potential of soil. The basis for generating mapping units were a classification of agro-climatic regions provided by the Information Service of the National Agricultural and Food Centre/Soil Science and Conservation Research Institute (NAFC-SSCRI, 2015), Land Parcel Identification System (LPIS) and Digital Soil Map of Slovakia.

\section{Results and discussion}

A multi-criteria approach to the spatial quantification of ecosystem services related to socio- 
economic indicators allows the explicit assessment of the potential of ecosystems of agricultural land to provide agroecosystem services. The proposed mapping system connects ecosystem service with landscape coverage. This is one of the conditions for using this model to monitor changes in land use management, spatial planning, and implementation of the assessment of the potential of natural capital services in socio-economic planning within the region and landscape. The distribution of the filtering potential using spatial mapping units is shown in Figure 1. In Slovakia 41.67 per cent of agroecosystems have very high filtering potential for inorganic pollutants.

Very high filtering potential is typical for ecosystems of arable land developed on loess located in the Danube and the Eastern Slovak Lowland without any anthropogenic and geochemical deposition. According to Greiner, L. et al. (2017) soil properties and soil functions are critical to ensure the provision of ecosystem services. These ecosystems located on Chernozems and Cutanic Luvisols, on soils characterized by high carbonate content with a neutral or slightly alkaline $\mathrm{pH}$ value (KoвzA, J. et al. 2014) and with high organic matter content, have the highest filtering potential. In Slovakia ecosystems of arable land of low filtering potential $(41.12 \%$ of the area) are predominantly located on Fluvisols (along Váh, Hron and Bodrog rivers). The low filtering potential of these ecosystems is due by a higher content of risk elements in alluvial sediments (anthropogenic deposition) in combination with the low potential of soil sorbents (Makovniková, J. 2001; Donisa, C. et al. 2003; Boruvka, L. and DrabeK, O. 2004; Makovniková, J. et al. 2007; Makovniková, J. and BARANČíkovÁ, G. 2009).

The mountain soils on grassland (Podzols, Dystric Cambisols located south-west and east of Banská Bystrica, east of Spišská Nová Ves, and in the mountain regions of Western Carpathians) are also strongly involved in the very low category of filtering potential. These soils are developed on substrates with higher content of risk elements due predominantly to parent material (geochemical anomalies) (ČurLík, J. 2011). Permanent grasslands are mostly at higher altitudes as well as on higher slopes, on soils with low sorption potential developed on substrates with higher content of risk elements (MaкоvNiková, J. et al. 2007; KовzA, J. et al. 2014). Most of the ecosystems of agricultural land with high potential for provisioning services belong to a category with very high or high filtering potential.

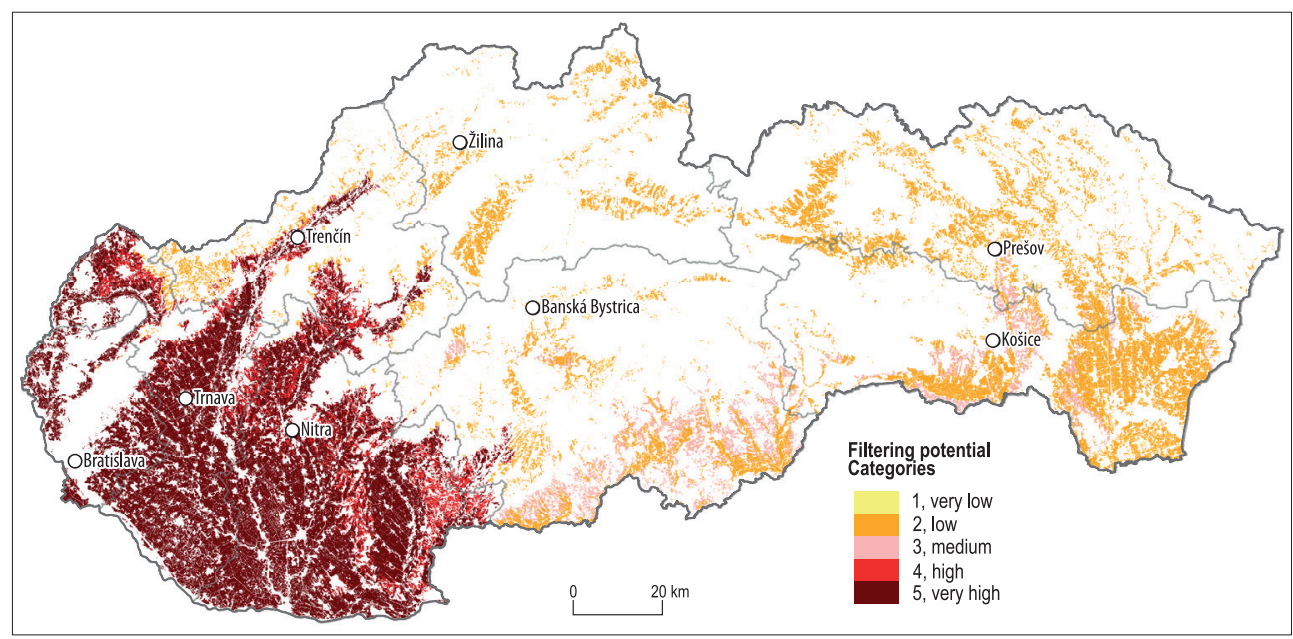

Fig. 1. The filtering potential of agroecosystems in Slovakia (edited by MAKovníková, J. and PÁLKA, B.) 
This proposed mapping system was used to assess agroecosystem service, filtering potential, in the regions of the Slovak Republic. There are currently eight regions of Slovakia and they correspond to the EU's NUTS 3 level of local administrative units. Each region consists of districts (there are currently 79 districts).

The distribution of the filtering potential using spatial mapping units in regions of Slovakia is illustrated in Figure 2. The variability within individual categories (minimum and maximum value) is shown in Table 1.

The distribution of the filtering potential using spatial mapping units in districts of Slovakia is illustrated in Figure 3.
In the Bratislava region more than 90 per cent of the total area of used agricultural land belongs to the category with a very high filtering potential for inorganic soil pollutants (see Figure 2 and 3). Only a small share of categories of high and moderate potential of this service can be found in this region.

In each district of the Nitra region, the category of very high filtering potential of soil pollutants varies from 71.40 per cent to 99.32 per cent (see Table 1) and category of high potential varies from 0.68 per cent to 21.69 per cent of the total area of used agricultural land. Only in three districts (Levice, Topol'čany and Nové Zámky districts) was determined a low

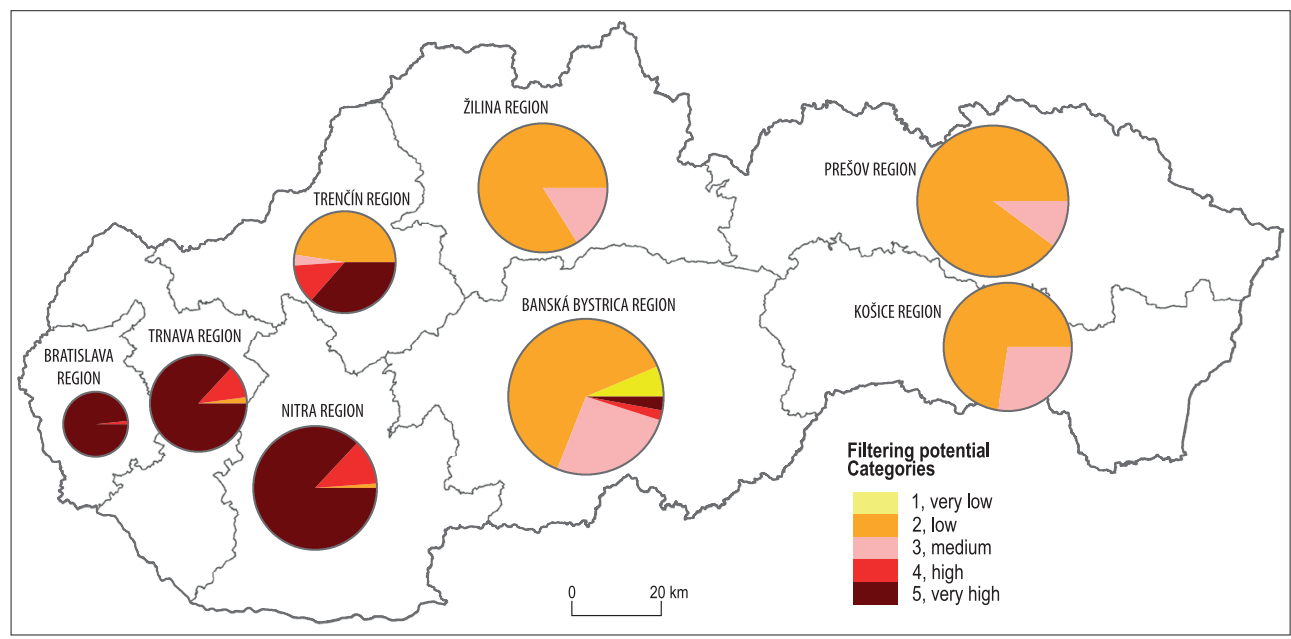

Fig. 2. The filtering potential for inorganic soil pollutants in regions of Slovakia (edited by MaKovNíková, J. and PÁLKa, B.)

Table 1. The variability (minimum-maximum) of filtering potential in regions

\begin{tabular}{l|r|r|r|r|r}
\hline \multirow{2}{*}{ Region/NUTs3 } & \multicolumn{5}{|c}{ Category of filtering potential in \% of used agricultural land } \\
\cline { 2 - 6 } & Very low & \multicolumn{1}{|c}{ Low } & Medium & \multicolumn{1}{c}{ High } & Very high \\
\hline Bratislava/SK010 & $0.00-0.08$ & $0.00-1.15$ & $0.02-0.15$ & $0.29-5.53$ & $94.45-99.71$ \\
Nitra/SK023 & $0.00-0.00$ & $0.48-6.31$ & $0.00-0.60$ & $0.68-21.69$ & $71.40-99.32$ \\
Trenčín/SK022 & $0.01-1.30$ & $1.61-93.29$ & $0.16-6.69$ & $0.00-29.46$ & $3.05-68.77$ \\
Trnava/SK023 & $0.00-0.00$ & $0.00-10.94$ & $0.00-0.83$ & $0.18-21.76$ & $73.04-98.87$ \\
Banská Bystrica/SK032 & $0.00-30.22$ & $37.54-96.79$ & $2.21-53.35$ & $4.24-22.07$ & $7.54-29.53$ \\
Žilina/SK031 & $0.10-4.71$ & $69.54-93.07$ & $6.14-29.18$ & $0.00-0.00$ & $0.00-0.00$ \\
Prešov/SK041 & $0.08-3.09$ & $82.03-95.93$ & $2.58-17.42$ & $0.00-0.00$ & $0.00-0.00$ \\
Košice/SK042 & $0.00-2.56$ & $12.32-94.56$ & $4.46-87.68$ & $0.00-0.00$ & $0.00-0.00$ \\
\hline
\end{tabular}




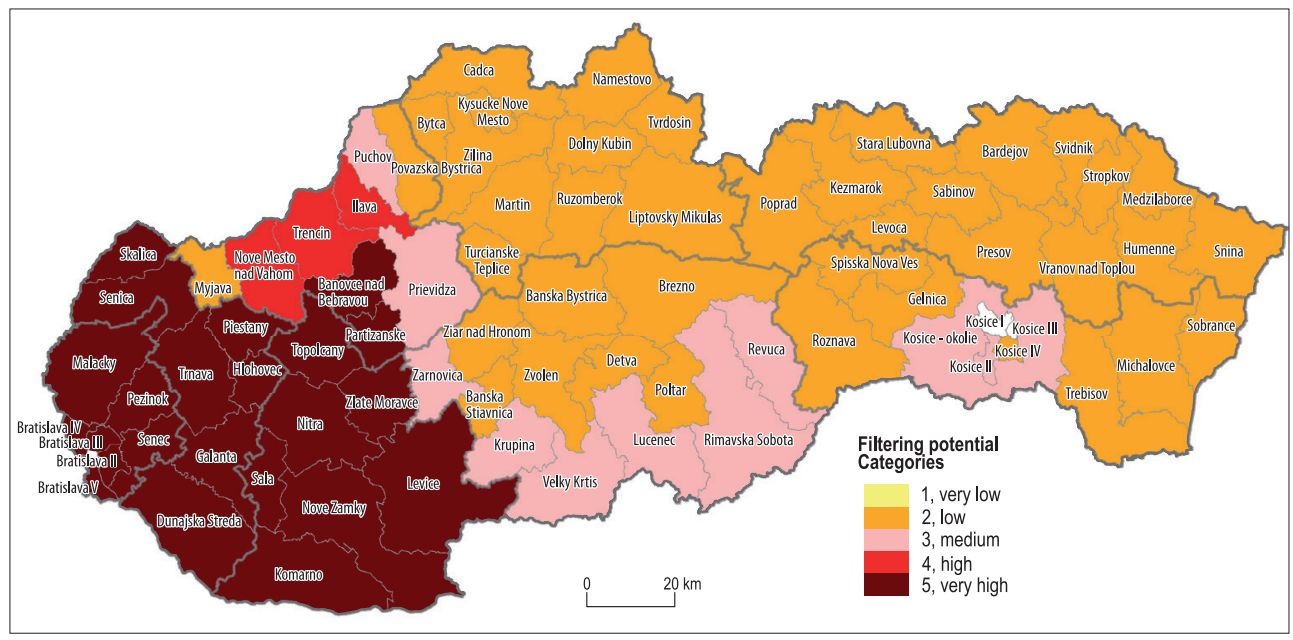

Fig. 3. The filtering potential for inorganic soil pollutants in districts of Slovakia (edited by MaкоvNíкоvá, J. and PÁlKa, B.)

category of filtering potential (from $0.48 \%$ to $6.31 \%$ of used agricultural land).

In the Trenčin region there is high variability among districts of this regulating service. In two districts (Myjava district and Považská Bystrica district) categories of low filtering potential are present in more than 80 per cent of the total area of used agricultural land. The share of the category of very high filtering potential ranges from 3.05 per cent (Myjava district) to 68.77 per cent (Partizánske district) of the total area of used agricultural land.

In the Trnava region share of the category of very high filtering potential ranges from 73.04 per cent (Senica district) to 98.87 per cent (Dunajská Streda district) and the category of high potential varies from 0.18 per cent (Dunajská Streda district) to 21.76 per cent (Skalica district) of the total area of used agricultural land. There is a small share of categories of low and moderate potential of this regulating service in four districts.

In the Banská Bystrica region there is a high category of low filtering potential for soil pollutants, in 3 districts (Banská Bystrica, Banská Štiavnica and Zvolen district) it is over 80 per cent and in eight districts more than 50 per cent of total area of used agricultural land.
High and very high potential for this regulating service is found in two southern districts (Krupina and Žarnovica district).

A majority of the districts of the Žilina region have a high proportion of categories of moderate and low potential for soil filtration. A significant percentage of the category of low filtering potential (lower than $90 \%$ ) is reported in seven districts from 13 districts in this region. Categories of high and very high potential are not represented in this region.

In the Prešov region the majority of districts have a high percentage area in the category of low filtering potential (ranges from $82.03 \%$ to $95.93 \%$ ). There is an absence of the categories of very high and high potential for this regulating service in this region.

In the Košice region a significant percentage of the category of low filtering potential (more than $80 \%$ ) is reported in three districts (Gelnica, Sobrance and Spišská Nová Ves district). The share of the category of medium filtering potential for soil pollutants ranges from 4.46 per cent (Gelnica district) to 87.68 per cent (Košice III district) of the total area of used agricultural land. Similar to Prešov and Žilina regions, categories of high and very high potential are not represented in this region. 
Because the provision of ecosystem service depends on biophysical, land use and climate (Makovniková, J. et al. 2007; Burghard, B. et al. 2014), the distribution of this service is geographically different. The greatest differences among regions was found in relation to climatic conditions, land use type and diversity of soil types. According to FréLICHOvá, J. and FANTA, J. (2015), the climate has an important impact on the distribution of agro-ecosystem services. In Slovakia there are very low and low categories of filtering potential characteristic of areas with a cold to moderately warm climate, higher slopes and a higher percentage of clay particles in soil texture. Very warm climatic region, low slopes and medium content of clay fraction are predominantly in areas with high and very high filtering potential. The climate and the substrate are among the major factors influencing the soil genesis. Climate also affects the management and land use. Land use types can have positive or negative impacts on the pedosphere multi-functionality in terms of its processes, functions and services (Dominati, E.J. et al. 2014). Intensive agricultural practices typically reduce soil organic matter content and negatively impact soil biodiversity, which are recognized as major drivers of the soil ecosystem process. The using of low quality inorganic fertilizers can increase anthropogenic soil load which negatively influence filtering potential (MAкоvNiкová, J. 2001).

\section{Conclusions}

In this study, the first assessment of one of the regulating agroecosystem services, soil filtration using spatial mapping units is applied. The evaluation of agroecosystem service linked to spatial visualization was used the assess the filtering potential in the regions of the Slovak Republic (using NUTS classification of regions of European Union countries NUTs 3). We conclude that this assessment and mapping allows us to link the analysis of natural capital, land use and filtering potential (one of the regulating agroecosystem services) in the regions and districts of the Slovak Republic.
The spatial mapping of ecosystem service is useful for providing guidelines and limits for policy development on land management and land use changes at local and regional levels.

In Slovakia very high filtering potential (for inorganic pollutants) is present in more than 41 per cent of agroecosystems, mostly in the Bratislava, Nitra and Trnava regions. On the other hand, more than 41 per cent of the total agricultural land belong to the category with low filtering potential. Ecosystems with very low filtering potential $(1.13 \%$ of the total agricultural land) are located at higher altitudes, steeper slopes, on soils with lower sorption potential as well as soils developed on substrates with higher content of risk elements, predominantly mountain soils. The greatest differences among regions ca be found in relation to climatic conditions, land use and diversity of soil types. The direct effect on filtering potential also has a degree of soil load due to anthropogenic or geochemical contamination.

It is important to note that agroecosystems are not able to provide ecosystem services without any intervention by humans (human and social capital). Inappropriate land management practices are negatively related to ecosystem condition and will result in ecosystem degradation that reduces the agroecosystem services provided (Dendoncker, N.F.et al. 2018). Appropriate land management can act to improve the capacity of natural capital to generate ecosystem services. However, increasing of primary and secondary production of agroecosystems must be managed with regard to the sustainability of the soil multi-functionality and the sustainability of potential of agroecosystem to provide ecosystem services in their integrity. The mapping of ecosystem services and their integration into regional decision making and the optimization of ecosystem services potential can contribute to the sustainable use of ecosystems.

Acknowledgement: The authors acknowledge the Slovak Research and Development Agency for the financial support via contract No. APVV-12-0098 "Analysis, modelling and evaluation of agroecosystem services", and APVV-18-0038 "Valuing ecosystems services of natural capital as a tool for assessing the socio-economic potential of the area". 


\section{REFERENCES}

Alam, M., Dupra, J. and Messier, C. 2016. A framework towards a composite indicator for urban ecosystem services. Ecological Indicators 60. 38-44.

Birghofer, K., Diehl, E., Andersson, J., Ekroos, J., FrüH-Müller, A., Machnikowski, F., Mader, V.L., Nilsson, L., Sasaki, K., Rundlöf, M., Wolters, V. and Sмiтh, H.G. 2015. Ecosystem services - current challenges and opportunities for ecological research. Frontiers in Ecology and Evolution 2 (12 January 2015). Available at: http://dx.doi. org/10.3389/fevo.2014.00087

BorûvkA, L. and Drábek, O. 2004. Heavy metals distribution between fractions of humic substances in heavily polluted soils. Plant Soil Environment 50. (8): 339-345.

Burkhard, B. and Maes, J. (eds.) 2017. Mapping Ecosystem Services. Advanced Books. Sofia, Pensoft Publishers. Available at: https://doi.org/10.3897/ ab.e12837

Burkhard, B., Kandziorai, M.S. and Müller, F. 2014. Ecosystem Service Potentials, Flows and Demands - Concepts for Spatial Localisation, Indication and Quantification. Official Journal of the International Association for Landscape Ecology - Regional Chapter Germany (IALE-D). Available at: http://www.landscapeonline.de/103097lo201434

Burkhard, B., Kroll, F., Müller, F. and Windhorst, W. 2009. Landscapes' capacities to provide ecosystem services - a concept for land-cover based assessments. Landscape Online 15. (1): 1-22.

Costanza, R., Groot, R., BraAt, L., Kubiszewski, I., Fioramonti, L., Sutton, P., Farber, S. and Grasso, M. 2017. Twenty years of ecosystem services: How far have we come and how far do we still need to go? Ecosystem Services 28. 1-16.

Coyle, C., Creamer, R.E., Schulte, R.P.O., O’Sullivan, L. and Jordan, P.A. 2016. Functional Land Management conceptual framework under soil drainage and land use scenarios. Environmental Science E Policy 56. 39-48. Available at: http://dx.doi. org/10.1016/j.envsci.2015.10.012

Čurlík, J. 2011. Potenciálne toxické stopové proky a ich distribúcia v pôdach Slovenska (Potentially toxic trace elements and their distribution in the soil of Slovakia). Bratislava, PriFUK. (In Slovak)

Dendoncker, N., Boeraeve, F., Crouzat, E., Dufręne, M., König, A. and Barnaud, C. 2018. How can integrated valuation of ecosystem services help understanding and steering agroecological transitions?. Ecology and Society 23(1):12. https://doi. org/10.5751/ES-09843-230112

Dominati, E.J. 2013. Natural capital and ecosystem services of soils. In Ecosystem services in New Zealand - conditions and trends. Ed.: Dymond, J.R., Lincoln, NZ, Manaaki Whenua Press, 132-142.
Dominati, E.J., Mackay, A., Lynch, B., Heath, N. and Millner, I. 2014. An ecosystem services approach to the quantification of shallow mass movement erosion and the value of soil conservation practices. Ecosystem Services 9. 204-215. Doi: 10.1016/j. ecoser.2014.06.006

Dominati, E.J., Patterson, M. and Mackay, A. 2010. A framework for classifying and quantifying the natural capital and ecosystem services of soils'. Ecological Economics 69. 1858-1868.

Donisa, C., Mocanu, R. and Steinnes, E. 2003. Distribution of some major and minor elements between fulvic and humic fractions in natural soils. Geoderma 111. 75-84.

Forouzangohar, M., Crossman, N.D., Richard, J., MacEwan, R.J., Dugal Wallace, O. and Bennett, L.T. 2014. Ecosystem Services in Agricultural Landscapes: A Spatially Explicit Approach to Support Sustainable Soil Management. Hindawi Corp. The Scientific World Journal 2014. Article ID 483298. http://dx.doi.org/10.1155/2014/483298

Frélichová, J. and FANTA, J. 2015. Ecosystem service availability in view of long-term land-use changes: a regional case study in the Czech Republic. Ecosystem Health and Sustainabilty 1. (10): 1-15.

Greiner, L., Keller, A., Gret-Regamey, A. and PAPritZ, A. 2017. Soil function assessment: review of methods for quantifying the contributions of soils to ecosystem services. Land Use Policy 69. 224-237.

Haines-Young, R., Potschin, M. and Kienast, F. 2012. Indicators of ecosystem service potential at European scales: mapping marginal changes and trade-offs. Ecological Indicators 21. 39-53.

Kobza, J., Barančí́Ková, G., Dodok, R., HrivŇÁKová, K., Makovníková, J., PÁlka, B., Pavlenda, P., Schlosserová, J., STYK, J. and ŠiráŇ, M. 2014. Monitoring pôd SR. Súčasný stav a vývoj monitorovaných vlastností pôd ako podklad $k$ ich ochrane a d'al'šiemu využívaniu (2007-2012). (Current state and development of monitored soil properties as a basis for their protection and further use [2007-2012]). Bratislava, NPPC-VUPOP. (In Slovak)

Maes, J., Burkhard, B. and Geneletti, D. 2018. Ecosystem services are inclusive and deliver multiple values. A comment on the concept of nature's contributions to people. One Ecosystem 3: e24720. Available at: https://doi.org/10.3897/ oneeco.3.e24720

Makovníková, J. 2001. Distribution of $\mathrm{Cd}$ and $\mathrm{Pb}$ in main soil types of Slovakia. Agriculture 47.903-912.

Makovníková, J. and Barancíková, G. 2009. Assessment of transport risk of cadmium and lead on the basis of Immobilisation capability of soil. Soil and Water Research 4. (1): 10-16.

Makovníková, J., Barančíková, G. and PÁlKa, B. 2007. Approach to the assessment of transport risk of inorganic pollutants based on the immobilisation capability of soil. Plant, Soil and Environment 53. 365-373. 
MEA Millennium Ecosystem Assessment 2005. Ecosystems and Human Well-Being: Our Human Planet: Summary for Decision Makers. The Millennium Ecosystem Assessment Series, Vol. 5. Washington DC, Island Press.

Rodríguez, J.P., Beard, D.T.Jr., Bennett, E.M., Cumming, G.S., Cork, S.J., Agard, J., Dobson, A.P. and Peterson, G.D. 2006. Trade-offs across Space, Time and Ecosystem Services. Ecology and Society 11(1): 28. http://ecologyandsociety.org/vol11/iss1/art28/
Spake, R., Lasseur, R., Crouzat, E., Bullock, J., Lavorel, S.E., Parks, K., SchaAfsma, M., Bennett, E., Maes, J., Mulligan, M., Mouchet, M., Peterson, G., Schulp, C., Thuiller, W., Turner, M., Verburg, P. and Eigenbrod, F. 2017. Unpacking ecosystem service bundles: towards predictive mapping of synergies and trade-offs between ecosystem services. Global Environmental Change 47. 37-50. 
